\title{
Bioactive metabolites from an endophytic Cryptosporiopsis sp. inhabiting Clidemia hirta
}

\begin{abstract}
Authors: Mahesh Kumar Zillaa, Masroor Qadrib, Syed Riyaz-Ul-Hassan, Anup Singh Pathaniac, Yedukondalu Nalli, Sunil Kumar, Santosh Kumar Guru, Shashi Bhushan, Gary A Strobel, Ram A Vishwakarmaa, \& Asif Alia
\end{abstract}

NOTICE: this is the author's version of a work that was accepted for publication in Phytochemistry, Changes resulting from the publishing process, such as peer review, editing, corrections, structural formatting, and other quality control mechanisms may not be reflected in this document. Changes may have been made to this work since it was submitted for publication. A definitive version was subsequently published in Phytochemistry, VOL\# 95, (November 2013).

DOI\#10.1016/j.phytochem.2013.06.021.

Zilla, M.K., Qadri, M., Ul- Hassan, S.R., Pathania, A.S., Nalli, Y., Kumar, S., Guru, S.K., Bhushan, S., Strobel, G.A., Vishwakarma, R., Ali, A. (2013) Isolation of bioactive metabolites from an endophytic fungus Cryptosporiopsis sp.of Clidemia hirta and their apoptotic potential. Phytochemistry 95: 291-297.

http://dx.doi.org/10.1016/j.phytochem.2013.06.021

Made available through Montana State University's ScholarWorks scholarworks. montana.edu 


\section{Isolation of novel bioactive metabolites from the endophytic fungus}

\section{Pezicula sp. and their apoptotic potential (working title)}

Mahesh Kumar Zilla ${ }^{\mathrm{a}, \mathrm{e}}$, Masroor Qadri ${ }^{\mathrm{b}, \mathrm{e}}$, Syed Riyaz-Ul-Hassan ${ }^{\mathrm{b}}$, Anup Singh Pathania ${ }^{\mathrm{c}, \mathrm{e}}$, Yedukondalu Nalli ${ }^{\mathrm{a}}$, Sunil Kumar ${ }^{\mathrm{a}}$, Santosh Kumar Guru , Shashi Bhushan ${ }^{\mathrm{c}}$, Gary A Strobel ${ }^{\mathrm{d}}$, Ram A Vishwakarma ${ }^{\mathrm{a}, *}$, Asif Ali ${ }^{\mathrm{a}, *}$

${ }^{a}$ Natural Product Chemistry Division, Indian Institute of Integrative Medicine, Canal Road, Jammu 180001, India.

${ }^{b}$ Biotechnology Division, Indian Institute of Integrative Medicine, Canal Road, Jammu 180001, India.

${ }^{c}$ Pharmacology Division, Indian Institute of Integrative Medicine, Canal Road, Jammu 180001, India.

d Department of Plant Sciences, Montana State University, Bozeman, MT 59717, USA.

${ }^{\mathrm{e}}$ These authors contributed equally to this work

E-mail: asifali@iiim.ac.in; ram@iiim.ac.in

Tel.: +91-191-2569222. Fax: +91-191-25693331. 


\section{Abstract:}

H2-1, depicting 95\% homology in its ITS region with Pezicula sp., was isolated as an endophyte from Clidemia hirta and several novel bioactive metabolites were recovered from it. These compounds were purified from broth cultures of the fungus and their structures were determined by spectroscopic methods as $(R)$-5-hydroxy-2-methylchroman-4-one (1), 1-(2,6dihydroxyphenyl)pentan-1-one (2) and (Z)-1-(2-(2-butyryl-3-hydroxyphenoxy)-6hydroxyphenyl)-3-hydroxybut-2-en-1-one (3). Among all the three compounds, 1 exhibited potent cytotoxic activity in human leukemia_cells, HL-60 ( $\mathrm{IC}_{50} 4 \mu \mathrm{g} / \mathrm{ml}$ ). Interestingly, compound 1 also significantly induced G2 arrest of the HL-60 cell cycle. In addition, out of the three compounds, $\mathbf{2}$ and $\mathbf{3}$ were active against several bacterial pathogens, with $\mathrm{IC}_{50}$ ranging from 6-75 $\mu \mathrm{g} / \mathrm{ml}$. Compound 2 showed activity against B. cereus, E. coli and $S$. aureus with $\mathrm{IC}_{50}$ values from $18-30 \mu \mathrm{g} / \mathrm{ml}$, whereas compound $\mathbf{3}$ showed very potent activity against $P$. fluorescens with an $\mathrm{IC}_{50}$ value of $6 \mu \mathrm{g} / \mathrm{ml}$. However, none of the compounds displayed any anti-fungal activity. Note- the abstract is great. The title should have a fungal name 95\% homology is acceptable for Pezicula- try Cryptosporiopsis for a match- do not use a culture number because it means nothing. You might use Cryptosporiopsis since it is the imperfect stage of Pezicula.??

Keywords: Clidemia hirta, Pezicula species, Endophytes, Natural products, Antimicrobial activity, Cytotoxicity. 


\section{Introduction:}

Endophytes are microbial entities that live within living tissues of plants without any apparent deleterious consequences to their host (Strobel et al., 2003). Endophytic fungi represent an outstanding source of bioactive natural products because there are so many of them occupying literally millions of unique biological niches (higher plants) growing in diverse environments. Thus, it appears that these biotypical factors can be important for plant selection, since they may govern the novelty and biological activity of the products associated with endophytic microbes (Strobel et al., 2003; Porras-Alfaro and Paul Bayman, 2011). The discovery of world's first billion-dollar anticancer compound (Taxol) was discovered in Taxomyces andreanae, a fungus that colonizes the Pacific yew, thus interest in studying such endophytes for their medicinal potential has grown tremendously (Stierle et al., 2003). In recent years, endophytes have been most extensively studied for their ability to produce antibacterial, antiviral, anticancer, antioxidant, antidiabetic and immunosuppressive compounds (Gou et al., 2008). In this report, we describe the isolation and characterization of three distinct natural bioactive metabolites with anticancer and antimicrobial activities.

\section{Results and Discussion:}

The endophytic fungus was isolated as described previously by (Ezra et al. 2004) from the plant tissues (small twigs) of Clidemia hirta found in Hawaii (Fig. 1). The culture did not produce any spores, thus the microscopic identification was inconclusive. However, aquistion of the ITS-5.8S-ITS2 ribosomal gene sequence showed that the organism was phylogenetically related to Pezicula/Cryptosporiopsis, displaying the highest sequence 
similarity of $95 \%$ with Pezicula sporulosa and P. cinnamomea, and $94 \%$ with Cryptosporiopsis diversispora. The evolutionary position of $\mathrm{H} 2-1$ is presented in (Fig. S3 in supporting information). Since this organism dispayed a unique phylogenetic position, it was selected as a potential candidate for the isolation of lead natural products. The culture was submitted to the National Fungal Culture Collection of India under the Voucher No. NFCCI 2856. For isolation of secondary metabolites, the culture was grown in potato dextrose broth (5L) at $25^{\circ} \mathrm{C}$ and $200 \mathrm{rpm}$ for 15 days. The fermentation broth was filtered through cheese cloth and extracted with ethyl acetate, which afforded $2.0 \mathrm{~g}$ of crude extract. Flash column chromatography of the crude extract on silica gel and further purification with HPLC led to the isolation of compounds $\mathbf{1 - 3}$ (Fig. 1). The structures of compounds $\mathbf{1 - 3}$ were assigned by ${ }^{1} \mathrm{H},{ }^{13} \mathrm{C}$ NMR spectroscopy with connectivity established by two-dimensional techniques (COSY, HSQC, and HMBC, NOESY). Assignments were confirmed by comparison with literature values when possible.

The optically active compound $\mathbf{1}[\alpha]_{\mathrm{D}}^{25}=+7.3$ was isolated as a brownish colour semisolid substance $(80 \mathrm{mg})$ with m.p. $35-37^{\circ} \mathrm{C}$. It possessed a retention time in HPLC $\mathrm{R}_{\mathrm{t}}$ of $10.2 \mathrm{~min}$ in solvent system $\mathrm{CH}_{3} \mathrm{CN}: \mathrm{H}_{2} \mathrm{O}(3: 7)$ under the proscribed conditions.

The HR-ESIMS of 1 yielded molecular ions with a peak at $\left(\mathrm{m} / \mathrm{z} 179.0679[\mathrm{M}+1]^{+}\right.$which was further supported by ${ }^{1} \mathrm{H},{ }^{13} \mathrm{C}$ and $2 \mathrm{D}$ NMR spectral data in (Table 1) thus authenticating that the molecular formula of $\mathbf{1}$ was $\mathrm{C}_{10} \mathrm{H}_{10} \mathrm{O}_{3}$, which is similar, but not identical, to that of the known molecule 2,3-dihydro-5-hydroxy-2-methylchromen-4-one, (Gray et. al 1999). It is to be noted that the absolute configuration of the stereogenic centre of methyl signal at C-2 position in compound $\mathbf{1}$ has not been established. The ${ }^{1} \mathrm{H}$ NMR of $\mathbf{1}$, displayed a three proton spin system at $\delta 6.42(\mathrm{~d}, J=8.3 \mathrm{~Hz}, 1 \mathrm{H}), 6.49(\mathrm{~d}, J=8.3 \mathrm{~Hz}, 1 \mathrm{H})$, and $7.35(\mathrm{t}, J=8.3 \mathrm{~Hz}$, $1 \mathrm{H})$, which suggested the presence of a tri-substituted aromatic system. A multiplet at $\delta 4.52$ $4.56(1 \mathrm{H})$ suggested the presence of an oxygen atom in the structure while a two-proton 
multiplet spin system at $\delta 2.64-2.81$ indicated the presence of a diastereotopic methylene group. A doublet at $\delta 1.51(\mathrm{~d}, J=6.3 \mathrm{~Hz}, 3 \mathrm{H})$ suggested that the methyl group was coupled to the multiplet at 4.56. An exchangeable proton at $\delta 11.71(1 \mathrm{H}, \mathrm{s})$ indicated a phenolic proton hydrogen-bonded to a carbonyl group which was authenticated by a ${ }^{13} \mathrm{C}$ NMR signal at $\delta$ 198.5 suggesting the presence of a carbonyl group. The 2D (COSY, HSQC, HMBC) NMR spectral correlations (Table 1) allow the unambiguous assignment of the all positions_(Table

\section{1). Always put the table or fig ref at the end of the sentence}

The relative configuration of compound $\mathbf{1}$ was mainly elucidated from NOESY correlation as being compatible with computer modelling in which the close contacts of atoms in space calculated were consistent with NOESY correlation (Fig. 2). For instance, in the NOESY correlation, H-2 exhibited a correlation with $\mathrm{H}-3$ indicating that these two protons $(\mathrm{H}-2$ \& $\mathrm{H}-$ 3) and were situated in the same face and assigned as $\alpha$-protons. From the above evidence, the relative configuration of the chiral carbon of compound $\mathbf{1}$ was assumed to be $2 \mathrm{R}^{*}$ (See the spectral data in Supporting information S10). On the basis of all considerable spectral data analyses, we conclude that the structure of $\mathbf{1}$ as being was identified as $(R)-5$-hydroxy-2methylchroman-4-one as a brownish colour semisolid.

The compound 2 was isolated as a colorless amorphous solid. The HR-EIMS exhibited the molecular ion peak at $\mathrm{m} / \mathrm{z} 217.1034[\mathrm{M}+\mathrm{Na}]^{+}$which waswere further authenticated by ${ }^{13} \mathrm{C}$ NMR spectroscopic data confirming that the molecular formula of compound $\mathbf{2}$ was $\mathrm{C}_{11} \mathrm{H}_{14} \mathrm{O}_{3}$. The IR spectrum of 2 suggested the presence of hydroxyl groups $\left(3408 \mathrm{~cm}^{-1}\right)$, and a conjugated ketone, $1677 \mathrm{~cm}^{-1}$, respectively, while the UV spectrum possessed $\lambda_{\max }$ values at 232, 274 and $324 \mathrm{~nm}$. The ${ }^{1} \mathrm{H}$ NMR spectrum (Table 2) exhibited the presence of methyl signal at $\delta 1.01(\mathrm{t}, J=7.6 \mathrm{~Hz})$, and other three methylene functionalities resonating at $\delta 3.12$ (t, $J=8.0), 1.77(\mathrm{dd}, J=7.4,7.4), 1.25$ (s), with three aromatic methines resonating at $\delta 7.23$ (t, $J=16.4 \mathrm{~Hz}, 2 \mathrm{H}), 6.38(\mathrm{~d}, J=8.2 \mathrm{~Hz}, 1 \mathrm{H})$ respectively. Analysis of the coupling pattern of 
the ${ }^{1} \mathrm{H}$ NMR spectrum showed the presence of three vicinal protons on a benzene nucleus. The remaining substituent's are in a symmetrical arrangement because the usual meta coupling is missing (Table 2). An exchangeable proton at $\delta 9.39(2 \mathrm{H}, \mathrm{s})$ indicated two phenolic proton hydrogen-bonded to a carbonyl group which was further authenticated by a peak at $\delta 207.6$ in the ${ }^{13} \mathrm{C}$ NMR spectrum supporting the presence of a carbonyl group in compound 2. ${ }^{13} \mathrm{C}$ NMR (Table 2) signals for 11 Carbon atoms and the DEPT spectrum indicatedes the presence of one methyl, three methylene, three methines and four quaternary carbon atoms.

The COSY, HSQC and HMBC correlations enabled the construction of the pentan-1-one in the side chain which is attached to the aromatic nucleus (Table 2). The remaining hydroxyl group substituents are based on the chemical shift of the relevant carbon atoms in the ${ }^{13} \mathrm{C}$ NMR spectrum. On the basis of all the relevant spectral data analyses, the compound 2 was characterized as 1-(2,6-dihydroxyphenyl) pentan-1-one (Fig. 1). This compound is new as a natural product, although the similar skeleton of this compound was reported by (Dai et. al, 2006) except the one methlene substitution in the side chain had not been previously reported.

\section{This is a perfect sentence explaining the findings.}

Compound (3) was obtained as a colorless solid. The molecular formula was assigned as $\mathrm{C}_{20} \mathrm{H}_{20} \mathrm{O}_{6}$ on the basis of HR-ESIMS which corresponds to $m / z 357.1485[\mathrm{M}+\mathrm{H}]^{+}$(calcd 356.1260). The IR absorption bands indicated the presence of hydroxyl $\left(3435,3358 \mathrm{~cm}^{-1}\right)$, carbonyl $\left(1726,1682,1651 \mathrm{~cm}^{-1}\right)$, and aromatic ring $\left(1619,1551,1446 \mathrm{~cm}^{-1}\right)$ groups, and UV absorptions at 256, 268, and $326 \mathrm{~nm}$ thus suggesting a conjugated aromatic ring system. The ${ }^{1} \mathrm{H},{ }^{13} \mathrm{C}$, and DEPT NMR spectral data (Table 3) authenticate 20 carbons atoms and 20 hydrogen atoms where as the DEPT indicates 20 carbon atoms containing two Methyl $\left(\mathrm{CH}_{3}\right)$, two Methylene $\left(\mathrm{CH}_{2}\right)$, seven methine $(\mathrm{CH})$ and nine quaternary $(\mathrm{C})$ carbon atoms. The ${ }^{1} \mathrm{H}$ NMR spectrum revealed six aromatic protons of a 1,2,3-trisubstituted benzene signal at $(\delta \mathrm{H}$ 
$7.53,7.21,6.89,6.80$ and 6.41$)$. Correspondingly, the carbon signals resonated at ( $\delta \mathrm{C} 135.6$, 136.0, 107.1, 111.03 and 108.5), suggesting a hexasubstituted benzene derivative with a methine $(\mathrm{CH})$ substitution resonated at $\delta \mathrm{H} 6.13(\delta \mathrm{C} 109.5)$. The four respective carbon signals resonated at downfield ( $\delta \mathrm{C} 168.0,161.3,160.6$ and 156.8), two carbonyls ( $\delta \mathrm{C} 207.8,183.7)$, two methylene $(\delta \mathrm{H} 3.13,1.77)$ and two methyls $(\delta \mathrm{H} 2.40,1.00)$. In addition, an exchangeable proton singlet at $\delta 12.47(1 \mathrm{H})$ and $9.92(2 \mathrm{H})$ indicated three phenolic protons hydrogenbonded to a carbonyl group which was further authenticated with ${ }^{13} \mathrm{C}$ NMR signals at $\delta 207.8$ and 183.7 indicating the presence of a carbonyl group in compound $\mathbf{3}$. The NMR data of $\mathbf{3}$ exhibited the dimmeric skeleton of reported compounds e.g. 3-hydroxy-1-(2,6dihydroxyphenyl)-butan-1-one and 1-(2,6-dihydroxyphenyl)-butan-1-one, (Dai et. al., 2006) with except for a few exceptions in functionalities (Fig. 1). The extended proton spin systems were identified, from $\mathrm{H}-4$ to $\mathrm{H}-5,6$ and from $\mathrm{H}-4$ ' to $\mathrm{H}-5$ ', 6' in the ${ }^{1} \mathrm{H}-{ }^{1} \mathrm{H}$ COSY spectrum. The carbonyl group C-7 ( $\delta \mathrm{C} 183.7)$ and C-7' (207.8), from H-6 ( $\delta \mathrm{H} 6.86), \mathrm{H}-8(\delta \mathrm{H} 6.13)$ and H-6' ( $\delta \mathrm{H} 6.41), \mathrm{H}-8^{\prime}(\delta \mathrm{H} 3.13), \mathrm{H}-9$ ' ( $\left.\delta \mathrm{H} 1.77\right)$ to the ketone carbonyl indicated as the HMBC correlations (Fig. 2). One signal, assigned to a trans configured double bond H-8 ( $\delta \mathrm{H} 6.13$ ), correlated with a carbonyl group C-7 ( $\delta \mathrm{C} 183.7)$ and $\mathrm{C}-2$ ( $\delta \mathrm{C} 110.3)$ and $\mathrm{C}-10(\delta \mathrm{C} 20.6)$, which suggested the presence of a 3-hydroxybuten-one $\left[-\mathrm{C}(\mathrm{O})-\mathrm{CH}-\mathrm{C}(\mathrm{OH})-\mathrm{CH}_{3}\right]$ moiety located at C-2. The others substitution in the aromatic ring HMBC correlations of $\mathrm{H}-8^{\prime}(\delta \mathrm{H}$ 3.13) with C-7' ( $\delta \mathrm{C} 207.8)$ and C-9' ( $\delta \mathrm{C} 17.7), \mathrm{C}-10^{\prime}(\delta \mathrm{C} 13.9)$ and of H-9' $(\delta \mathrm{H} 1.77)$ with C$10^{\prime}(\delta \mathrm{C} 13.9)$ and $\mathrm{C}-8^{\prime}(\delta \mathrm{C} 46.7)$ also revealed the existence of a $2^{\prime}$-oxobutane group $[-\mathrm{C}(\mathrm{O})-$ $\left.\mathrm{CH}_{2}-\mathrm{CH}_{2}-\mathrm{CH}_{3}\right]$ located at $\mathrm{C}-2$ '. The attachment of a hydroxyl group at $\mathrm{C}-9$ was supported by the HMBC correlations of the hydroxyl proton $(\delta \mathrm{H} 12.47)$ with $\mathrm{C}-8(\delta \mathrm{C} 109.5)$ and $\mathrm{C}-1(\delta \mathrm{C}$ 160.6) which was further supported by the NOESY correlation data. Furthermore, the H-8 exhibited a correlation with $\mathrm{H}-10$ indicating that these two protons (H-8 \& H-10) were situated in the same face (See the supporting information S24). On the basis of key spectral 
lines of evidence, the structure of compound 3 was established as (Z)-1-(2-(2-butyryl-3hydroxyphenoxy)-6-hydroxyphenyl)-3-hydroxybut-2-en-1-one.perfect!!

\section{1. Inhibition of cancer cell proliferation by isolated molecules:}

Using conventional tetrazolium based calorimetric assay (MTT assay), the cytotoxicity of the three isolated compounds (1-3) were evaluated in human myeloid leukemia cell line, HL-60, human pancreatic cancer cell line, MiaPaca-2 and human prostate cancer cell line, PC-3. Among the three metabolites, compound $\mathbf{1}$ was the most cytotoxic in comparison to the other molecules. Compound 3 was not cytotoxic in all the above mentioned cancer cell lines (IC50>100 $\mu \mathrm{g} / \mathrm{ml}$ ) whereas Compound 2 possessed a comparatively high (two to four times) the cytotoxic $\mathrm{IC}_{50}$ value in comparison to $\mathbf{1}$. Among three isolated molecules, $\mathbf{1}$ was the most cytotoxic with $\mathrm{IC}_{50}$ values of 4,16 and $86 \mu \mathrm{g} / \mathrm{ml}$ in HL-60, MiaPaca-2 and PC-3 cells, respectively (Fig. 3). Therefore, 1 was selected for further time dependent cytotoxic and apoptosis studies in HL-60 cells and there was a time dependeant decrease in the cytotoxic $\mathrm{IC}_{50}$ value of 1 (from $31 \mu \mathrm{g} / \mathrm{ml}$ to $4 \mu \mathrm{g} / \mathrm{ml}$ ) in HL-60 cells (Fig. 3).

2. 2. Compound 1 altered whole cells and nuclear morphology: Treatment of human leukaemia HL-60 cells with 1 at 10, 20 and $30 \mu \mathrm{g} / \mathrm{ml}$ concentrations caused cell wall deformation, shrinkage of cell size, nuclear condensation and formation of scattered apoptotic bodies while the nuclei of untreated cells remained round in shape as shown by arrows (Fig. 4a,b). The number of apoptotic bodies increased with increased concentration of 1 in HL-60 cells. This revealed that $\mathbf{1}$ induced cell death through induction of apoptosis in HL-60 cells.

\section{3. Compound 1 increases sub-G0 DNA fraction and G2/M arrest of cell cycle phase}

distribution: HL-60 cells exposed to 10,20 and $30 \mu \mathrm{g} / \mathrm{ml}$ concentrations of 1 up to $24 \mathrm{~h}$ exhibited continuous increase in sub-G0 fraction $(<2$ nDNA) which may comprise both apoptotic and debris fraction implying together the extent of cell death (Fig. 4c). Untreated cells showed 1\% sub-G0 DNA fraction while 1 treated HL-60 cells have 50\% and 78\% sub- 
G0 DNA fraction at $20 \mu \mathrm{g} / \mathrm{ml}$ and $30 \mu \mathrm{g} / \mathrm{ml}$ concentrations, respectively. Interestingly, $\mathbf{1}$ also induces G2/M phase arrest of HL-60 cells cycle with concurrent rise in its concentrations. Untreated cells show only 5\% G2/M fraction which was raise up to $81 \%$ at $30 \mu \mathrm{g} / \mathrm{ml}$ concentration of 1 (Fig. 4c).

2.4. Antimicrobial activities: All the three compounds (1-3) were evaluated for antimicrobial activities against a panel of important bacterial pathogens and the fungal pathogen, Candida albicans (Table 4). Compound $\mathbf{1}$ did not show any antimicrobial activity (up to a concentration of $100 \mu \mathrm{g} / \mathrm{ml}$ ) whereas Compounds 2 and $\mathbf{3}$ were active against several pathogens representing both Gram positive and Gram negative bacteria. These compounds were active against Bacillus cereus, E. coli, Listeria monocytogenes, Pseudomonas fluorescens, Shigella flexneri and Staphylococcus aureus. Although Compound 2 showed more activity against most of these pathogens, as depicted by lower $\mathrm{IC}_{50}$, Compound 3 showed exclusive activity against Streptococcus pyogenes and very potent activity ( $\mathrm{IC}_{50}: 6$ $\mu \mathrm{g} / \mathrm{ml}$ ) against $P$. fluorescens. Compound $\mathbf{2}$ showed significantly higher activities against $B$. cereus, E. coli and S. aureus, though none of the compounds displayed any significant antifungal activity.

\section{Conclusion:}

In conclusion, the present results suggest that Compounds $\mathbf{1}$ exhibit strong apoptotic and cytotoxic potential in human leukaemia HL-60 cells, whereas compounds $\mathbf{2}$ and $\mathbf{3}$ were found potentially active against several pathogens representing both Gram positive and Gram negative bacteria. Further, compound 1 exhibited strong G2 arrest in HL-60 cells, therefore we are exploring its role in cyclin and cyclin dependeant kinase regulation, this work at will be reported separately. The metabolites described in this study have been reported for the first time from this group of fungi. However, several other bioactive metabolites, for example cryptocandin and cryptocin, have been earlier described from them. This indicates that the 
Pezicula/Cryptosporiopsis group and related fungi are important sources of bioactive metabolites and exploration of these microbes may further contribute to the global natural product repository (Strobel et al., 1999; Li et al, 2000). These results exhibited the usefulness of compounds 1-3 in its development as novel anticancer or antibacterial therapeutic agents from this endophytic fungus.

\section{Experimental:}

4.1. General Experimental Procedure: UV and IR spectra were taken on a Perkin-Elmer Lambda $25 \mathrm{UV} /$ Vis spectrometer and FT-IR recorded Bio-Rad FTS-40A spectrometer. ${ }^{1} \mathrm{H}$, ${ }^{13} \mathrm{C}$, and $2 \mathrm{D}$ NMR experiments were accomplished on a Brucker, $400 \& 500 \mathrm{MHz}$ spectrometer. High-resolution mass spectral data were obtained on an Agilent 6540 UHD Accurate Mass (Q-ToF) Mass Spectrometer, (LTQ XL/LTQ Orbitrap Discovery) coupled to a Agilent 1290 series LC system (Agilent PDA detector, autosampler, and thermostat, (thermostatted column compartment, binary pump). The following conditions were used: capillary voltage $3500 \mathrm{~V}$, capillary temperature $350{ }^{\circ} \mathrm{C}$, auxiliary gas flow rate $7.0 \mathrm{~L} / \mathrm{min}$, spray voltage $4.5 \mathrm{kV}$, mass range 100-1000 amu (maximum resolution 30000). HPLC separations were made using waters spherisorb reversed-phase (C18, 250 X 10 mm, L i.d.) column connected to an Agilent 1200 series binary pump and monitored using an Agilent photodiode array detector. Detection was carried out at 220, 230, 254, 280, and $350 \mathrm{~nm}$. Diaion HP-20 was obtained from Sigma Aldrich. RPMI-1640, 3-(4, 5, -dimethylthiazole-2yl)-2, 5 diphenyltetrazolium bromide (MTT), Rhodamine-123 (Rh-123), penicillin, streptomycin, L-glutamine, pyruvic acid Propidium iodide(PI), Hoechst 33258, minimum essential medium (MEM), Fetal bovine serum were purchased from Sigma-Aldrich Co., India.

4.2 Fungal material and identification: The endophytic fungus was isolated as described previously by (Ezra et al. 2004). Plant tissues (small twigs) of Clidemia hirta, were 
thoroughly washed with running tap water, cut under sterile conditions into small pieces (2-3 $\mathrm{cm}$ ) and surface sterilized with $1 \%$ sodium hypochlorite and $70 \%$ ethanol. Before the treatment with alcohol, traces of sodium hypochlorite were removed by washing the plant sample in sterile distilled water. The outer tissues were removed and the internal tissues were cut into small pieces of 0.5 to $1 \mathrm{~cm}$ and plated on water agar (Difco). The plates were incubated at $25^{\circ} \mathrm{C}$ for three weeks. Hyphal tips of the fungus, emerging out of the plant tissue, were picked and grown on potato dextrose agar (Difco) in pure culture. The culture was also submitted to the National Fungal Culture Collection of India under the Voucher No. NFCCI 2856. For the extraction of secondary metabolites, the culture was grown in shake flasks in $\mathrm{PD}$ broth at $25^{\circ} \mathrm{C}$ and $200 \mathrm{rpm}$ for 15 days.

4.2. 1. Phylogenetic analysis by ITS1-5.8S-ITS2 ribosomal gene sequencing: Phylogenetic analysis of H2-1 was carried out by the acquisition of the ITS1-5.8S-ITS2 ribosomal gene sequencing. The ITS regions of the fungi were amplified with the universal ITS primers, ITS4 (5'TCCTCCGCTTATTGATATGC3') and ITS5 5'GGAAGTAAAAGTCGTAACAA3'), using the polymerase chain reaction (PCR). The PCR conditions used were as follows: initial denaturation at $94^{\circ} \mathrm{C}$ for $3 \mathrm{~min}$ followed by 30 cycles of $94^{\circ} \mathrm{C}$ for $15 \mathrm{sec}$., $55^{\circ} \mathrm{C}$ for $30 \mathrm{sec}$, $72^{\circ} \mathrm{C}$ for $45 \mathrm{sec}$, and a final extension at $72{ }^{\circ} \mathrm{C}$ for $7 \mathrm{~min}$. The $50 \mu 1$ reaction mixture contained $1 \times$ PCR buffer, $200 \mu \mathrm{M}$ each dNTP, $1.5 \mathrm{mM} \mathrm{MgCl}_{2}, 10$ pmol. of each primer, $1-5 \mathrm{ng}$ of DNA and 2.0 U of Taq DNA polymerase. The amplified product $(5 \mu \mathrm{l})$ was visualized on $1 \%$ (w/v) agarose gel to confirm the presence of a single amplified band. The amplicon was purified by Amicon Ultra columns (Millipore, USA) and 20-40 ng were used in a $10 \mu \mathrm{l}$ sequencing reaction using the Big Dye Terminator sequencing kit (v. 3.1). Twenty five cycles of $96^{\circ} \mathrm{C}$ for $10 \mathrm{~s}, 50^{\circ} \mathrm{C}$ for $5 \mathrm{~s}$ and $60^{\circ} \mathrm{C}$ for $4 \mathrm{~min}$ were performed and the extension products were purified by ethanol precipitation, dissolved in $10 \mu \mathrm{l}$ of HiDi Formamide, incubated at $95^{\circ} \mathrm{C}$ for 5 min and loaded on ABI Prism 377 Genetic Analyzer (Perkin-Elmer) 
for sequencing. All the reagents for sequencing were from Applied Biosystems, USA. The amplified product was sequenced and aligned with the sequences in the GenBank by BLASTN program (Altschul et al. 1997) to find out the sequence homology with closely related organisms. Sequences from the closely related organisms were downloaded a phylogenetic tree was constructed according to (Tamura et al. 2007). The ITS1-5.8S-ITS2 sequence was submitted to the GenBank under Accession Number JX683689.

4.2.2. Phylogenetic position: The fungus was associated as an endophyte with Clidemia hirta. The culture did not produce any spores, thus the microscopic identification was inconclusive. Aquistion of the ITS-5.8S-ITS2 ribosomal gene sequence showed that the organism was close to Pezicula/Cryptosporiopsis displaying the highest sequence similarity of 95\% with Pezicula sporulosa and P. cinnamomea, and 94\% with Cryptosporiopsis diversispora. The evolutionary position of $\mathrm{H} 2-1$ is presented in (Fig. S1 in supporting information). As this organism dispayed a unique phylogenetic position, it was selected as a potential candidate for isolation of novel natural products.

4.3. Extraction and Isolation of compounds (1-3): The $5 \mathrm{~L}$ of whole broth was homogenized with ethyl acetate $(1 \mathrm{~L})$ and filtered through a pad of Celite which was further extracted with ethyl acetate ( $1 \mathrm{~L} \mathrm{X} 2$ ). The crude extract was passed through the $\mathrm{Na}_{2} \mathrm{SO}_{4}$ and concentrated under reduced pressure in a rotary vacuum evaporator which afforded a dark brownish, oily residue ( $3.5 \mathrm{~g})$. The $3 \mathrm{~g}$ extract was subjected to flash column chromatography on silica gel (230-400 mesh), using a stepwise gradient of hexane in EtOAc to yield fifteen sub-fractions Fr.1-15. Fraction 6-14 which was eluted at 10\% EtOAc afforded $200 \mathrm{mg}$ with the mixture of three compounds with the very close $\mathrm{R}_{f}$ values which was further purified by semipreparative HPLC using (C-18 Column, $5 \mu, 10$ X $250 \mathrm{~mm}$, isocratic $\mathrm{H}_{2} \mathrm{O}-\mathrm{CH}_{3} \mathrm{CN}$ (7:3) for $50 \mathrm{~min}$, flow rate $1.0 \mathrm{~mL} / \mathrm{min}$, UV detection at $254 \mathrm{~nm}$ ). Compounds (1-3) were isolated 1 
$\left(80 \mathrm{mg}, \mathrm{t}_{\mathrm{R}}=10.2 \mathrm{~min}\right), \mathbf{2}\left(16 \mathrm{mg}, \mathrm{t}_{\mathrm{R}}=17.8 \mathrm{~min}\right)$ and $\mathbf{3}\left(8 \mathrm{mg}, \mathrm{t}_{\mathrm{R}}=31.6 \mathrm{~min}\right)$, were obtained under these conditions.

Compound (1): brownish colour semisolid; $[\alpha]^{25}{ }_{\mathrm{D}}+7.3\left(\mathrm{c} 0.1, \mathrm{CHCl}_{3}\right) ; \mathrm{UV}\left(\mathrm{CHCl}_{3}\right)$ : $\lambda_{\max }$ $(\log \varepsilon) 342$ (0.40), 254 (2.51), 220 (1.45), 203 (2.02) nm; ${ }^{1} \mathrm{H}$ and ${ }^{13} \mathrm{C}$ NMR spectra (400, 500 and $125 \mathrm{MHz}$, respectively), (See Table 1 and Fig. S4-S10, Supplementary data); (+)HRESIMS m/z 217.0140 $[\mathrm{M}+\mathrm{K}]^{+}(30), 179.0676[\mathrm{M}+1]^{+}(100), 163.0727[\mathrm{M}-\mathrm{Me}]^{+}(18)$, 137.0212 [M-CH2CO $]^{+}(13)$, HRESIMS $m / z$ 179.0676 $[\mathrm{M}+1]^{+}$(calcd for $\mathrm{C}_{10} \mathrm{H}_{10} \mathrm{O}_{3}$, 178.0630).

Compound (2): Colourless solid; m. p. $159{ }^{\circ} \mathrm{C},[\alpha]^{25} \mathrm{D}-4.6$ (c $\left.0.01, \mathrm{CHCl}_{3}\right)$; UV $\left(\mathrm{CHCl}_{3}\right)$ : $\lambda_{\max }(\log \varepsilon) 324$ (1.23), 274 (2.52), 232 (1.78), 226 (0.79) nm; IR (KBr) $v_{\max } 3408$ (br, OH), 1677, $668 \mathrm{~cm}^{-1} ;{ }^{1} \mathrm{H}$ and ${ }^{13} \mathrm{C}$ NMR spectra (See Table 2 and Fig. S12-S17, Supplementary data); (+)-HRESIMS $m / z 217.0741[\mathrm{M}+\mathrm{Na}]^{+}$, (calcd for $\mathrm{C}_{11} \mathrm{H}_{14} \mathrm{O}_{3}, 194.0943$ ).

Compound (3): Colourless solid; $[\alpha]^{25}+1.6\left(\mathrm{c} 0.01, \mathrm{CHCl}_{3}\right) ; \mathrm{UV}\left(\mathrm{CHCl}_{3}\right): \lambda_{\max }(\log \varepsilon) 326$ (1.23), 256 (2.10), 268 (2.01), $226(1.76) \mathrm{nm}$; IR (KBr) $v_{\max } 3445$ (br, OH), 1726, 1682, 1651, 1619, 1551, 1446, $668 \mathrm{~cm}^{-1} ;{ }^{1} \mathrm{H}$ and ${ }^{13} \mathrm{C}$ NMR spectra $(400,500$ and $125 \mathrm{MHz}$, respectively), (See Table 3 and Fig. S18-S25, Supplementary data) (+)-HRESIMS $\mathrm{m} / z$ $357.1485[\mathrm{M}+\mathrm{H}]^{+}(100), 314.1154\left[\mathrm{M}-\mathrm{CH}_{3}-\mathrm{C}-\mathrm{OH}\right]^{+}(55), 194.0673\left[\mathrm{M}-\mathrm{C}_{10} \mathrm{H}_{10} \mathrm{O}_{4}\right]^{+}$, 164.2024 (60) $\left[\mathrm{M}-\mathrm{C}_{10} \mathrm{H}_{12} \mathrm{O}_{2}\right]^{+} ;(+)$-HRESIMS $m / z 357.1485[\mathrm{M}+\mathrm{H}]^{+}$, (calcd. for $\mathrm{C}_{20} \mathrm{H}_{20} \mathrm{O}_{6}$, 356.3692).

\section{4. Biological activities:}

4. 4. 1. Cell Culture: Human promyelocytic leukemia cell lines HL-60, human pancreatic cancer cell line MiaPaca-2 and human prostate cancer cell line PC-3 was purchased from Sigma Aldrich, India (ECACC, type). HL-60 and PC-3 cells were grown in RPMI growth medium whereas MiaPaca-2 cells were grown in MEM medium containing 10\% FCS, $100 \mathrm{U}$ pencillin and100 mg streptomycin per $\mathrm{mL}$ medium. Cells were grown in $\mathrm{CO}_{2}$ incubator 
(Thermocon Electron Corporation, Houston, TX) at $37^{\circ} \mathrm{C}$ with $95 \%$ humidity and $5 \% \mathrm{CO} 2$ gas environment. Cells treated with tested materials were dissolved in DMSO while the untreated control cultures received only the vehicle (DMSO $<0.2 \%)$.

4. 4. 2. Cell proliferation Assay: Cells were seeded in 96 well plates and exposed to Compounds (1-3) at 1, 10, 30 and $50 \mu \mathrm{g} / \mathrm{ml}$ concentration for indicated time interval. MTT dye $(2.5 \mathrm{mg} / \mathrm{ml}$ in PBS) was added 4 hours priors to experiment termination. The plates were then centrifuged at $1500 \mathrm{rpm}$ for $15 \mathrm{~min}$ and the supernatant was discarded, while the MTT formazan crystals were dissolved in $150 \mu \mathrm{L}$ of DMSO. The OD measured at $570 \mathrm{~nm}$ with reference wavelength of $620 \mathrm{~nm}$ (Bhushan et al. 2006).

4. 4. 3. Apoptotic bodies' formation: Human leukemia HL-60 cells $\left(2 \times 10^{6} / 3 \mathrm{ml} / 6\right.$ well culture plates) were treated with compound 1 at 10,20 and $30 \mu \mathrm{g} / \mathrm{ml}$ concentration for 24 hours and examined under inverted microscope for apoptotic bodies formation. After phase contrast microscopy, cells were collected, washed with PBS twice and fixed in $400 \mu$ cold acetic acid: methanol $(1+3, \mathrm{v} / \mathrm{v})$ overnight at $4{ }^{\circ} \mathrm{C}$. The next day the cells were washed with fixing solution and dispensed in $50 \mu \mathrm{l}$ of fixing solution. The cells were spread on a clean slide and dried overnight at room temperature. Cells were stained with Hoechst 33258 $(5 \mu \mathrm{g} / \mathrm{ml}$ in $0.01 \mathrm{M}$ citric acid and $0.45 \mathrm{M}$ disodium phosphate containing $0.05 \%$ Tween 20$)$ for 30min at room temperature. After 30 min slides were washed with distilled water followed by in PBS. While wet, $40 \mu$ of mounting fluid (PBS: glycerol, 1/1) was poured over the slide and covered with glass cover slip and sealed with nail polish. Cells were observed under microscope for any nuclear morphological changes occurring in apoptosis (Bhushan et al. 2007).

4. 4. 4. DNA content and cell cycle phase distribution: HL-60 cells $\left(1 \times 10^{6} / 2 \mathrm{ml} / 12\right.$ well culture plate) were treated with 10,20 and $30 \mu \mathrm{g} / \mathrm{ml}$ concentrations of $\mathrm{H} 2 \mathrm{~A}-1$ for $24 \mathrm{~h}$. Cells were collected, washed in PBS, fixed in $70 \%$ cold ethanol and placed at $-20{ }^{\circ} \mathrm{C}$ overnight. 
Cells were washed with PBS, subjected to RNase digestion $(400 \mu \mathrm{g} / \mathrm{ml})$ at $37^{\circ} \mathrm{C}$ for $45 \mathrm{~min}$. Finally, cells were incubated with propidium iodide $(10 \mu \mathrm{g} / \mathrm{ml})$ for $30 \mathrm{~min}$ and analyzed immediately on flow cytometer FACSCalibur (Becton Dickinson, USA). The data were collected in the list mode on 10,000 events and illustrated in a histogram, where the number of cells (counts) is plotted against the relative fluorescence intensity of PI (FL-2; $\lambda$ em: 585 nm; red fluorescence). Resulting DNA distributions were analyzed by Modfit (Verity Software House Inc., Topsham, ME) for the proportions of cells in $\mathrm{G}_{0}-\mathrm{G}_{1}$, S- phase, and $\mathrm{G}_{2}$ M phases of the cell cycle (Saxena et al. 2010).

4. 4. 5. Determination of antimicrobial activities: The compounds isolated from H2-1 were evaluated for antimicrobial activities against a panel of pathogens (Table 4) including several bacteria and a fungal strain, Candida albicans. Stock solutions of each culture were prepared in Normal Saline Solution $(0.85 \% \mathrm{NaCl}(\mathrm{w} / \mathrm{v}))$ at a concentration of $10^{8}$ cells $/ \mathrm{ml}$. MuellerHinton (for bacteria) and PD broth (for C. albicans) were supplemented with the compound at concentrations, $100,50,25,12.5$ and $6.25 \mu \mathrm{g} / \mathrm{ml}$. Each well was inoculated with $10^{4}$ cells of the relevant test organism and incubated at $37^{\circ} \mathrm{C}$ for $24 \mathrm{~h}$. Absorbance was measured spectrophotometrically at $620 \mathrm{~nm}$ and $\mathrm{IC}_{50}$ of the extracts was calculated from the average percent inhibition of three replicates of each concentration (Ellof 1998).

\section{Acknowledgments}

M.K.S and M.Q are thankful to the Council of Scientific and Industrial Research (CSIR) for the financial assistance. We are thankful to Dr. Arvinda and Dipika Singh for NMR spectral data analysis. We are highly obliged to Dr. Ravikant Khajuria for recording the HR-EIMS. GAS thanks the US-NSF for their support of his work on endophytes.

\section{Supporting Information:}


NMR spectral data $\left({ }^{1} \mathrm{H},{ }^{13} \mathrm{C},{ }^{1} \mathrm{H}-{ }^{1} \mathrm{H}\right.$ COSY, HSQC and HMBC, NOESY) of compounds (1-3) along with a phylogenetic tree of H2-1; NFCCI 2856 of Clidemia hirta (Fig. S3) are available in supporting information.

\section{References:}

Strobel, G. A., Daisy, B., 2003. Bioprospecting for microbial endophytes and their natural products. Microbiol. Mol. Biol. Rev. 67, 491-502.

Porras-Alfaro, A., Bayman, P. 2011. Hidden fungi, emergent properties: endophytes and microbiomes. Annual Rev. Phytopath. 49, 291-315.

Strobel, G. A., 2003. Endophytes as sources of bioactive products. Microbes Infect. 5:535544.

Stierle A, Strobel GA, Stierle DB (1993) Taxol and taxane production by Taxomyces andreanae, an endophytic fungus of Pacific yew. Science 260:214-216

Guo, B., Wang, Y., Sun, X., Tang, K., 2008. Bioactive Natural Products from Endophytes: A Review. Appl. Biochem. \& Microbiol., 44, 136-142.

Ezra, D., Hess, W. H., Strobel, G. A., 2004. New endophytic isolates of M. albus, a volatile antibiotic-producing fungus. Microbiol. 150, 4023-4031.

Gray, L. E., Gardner, H. W., Weisleder, D., Leib, M., 1999. Production and toxicity of 2,3dihydro-5-hydroxy-2-methyl-4-H-1-benzopyran-4-one by Phialophora gregata. Phytochem., $50,1337-13340$.

Dai, J., Krohn, K., Flörke, U., Draeger, S., Schulz, B., Szikszai, A. K., Antus, S., Kurtán,T., Ree, T. N., 2006. Metabolites from the Endophytic Fungus Nodulisporium sp. From Juniperus cedre. Eur. J. Org. Chem. 3498-3506. 
Altschul, S. F., Madden, T. L., Schaffer, A. A., Zhang, J. H., Zhang, Z., Miller, W., Lipman, D. J., 1997. Gapped BLAST and PSI-BLAST: a new generation of protein database search programs. Nucleic Acids Res. 25, 3389-3402

Tamura, K., Dudley, J., Nei. M., Kumar, S., 2007. MEGA4: Molecular Evolutionary Genetics Analysis (MEGA) software version 4.0. Mol. Bio. Evol. 24, 1596-1599.

Bhushan, S., Singh, J., Rao, M. J., Saxena, A. K., Qazi, G. N., 2006. A novel lignan composition from Cedrus deodara induces apoptosis and early nitric oxide generation in human leukemia Molt -4 and HL-60 cells, Nitric oxide 14, 72-88.

Bhushan, S., Kumar, A., Malik, F., Andotra, S. S., Sethi, V. K., Kaur, I. P., Taneja, S. C., Qazi, G. N., Singh, J., 2007. A triterpenediol from Boswellia serrata induces apoptosis through both the intrinsic and extrinsic apoptotic pathways in human leukemia HL-60 cells, Apoptosis, 12, 1911-1926.

Saxena, A., Saxena, A. K., Singh, J., Bhushan, S. 2010. Natural antioxidants synergistically enhance the anticancer potential of AP9-cd, a novel lignan composition from Cedrus deodara in human leukemia HL-60 cells, Chemico-Biol. Inter. 188, 580-590.

Ellof, J. N., 1998. A sensitive and quick microplate method to determine the minimal inhibitory concentration of plant extracts for bacteria. Planta Med. 64, 711-713.

Strobel, G.A., Miller, R.V., Miller, C., Condron, M.., Teplow, D.B., and Hess, W.M., 1999. Cryptocandin, a potent antimycotic from the endophytic fungus Cryptosporiopsis cf. quercina Microbiol. 145, 1919-1926.

Li, J., Strobel, G.A. Harper, J., Lobkovsky, E., and Clardy, J. 2000. Cryptocin, a potent tetramic acid antimycotic from the endophytic fungus- Cryptosporiopsis quercina. Org. Lett. 2, 767-770. 


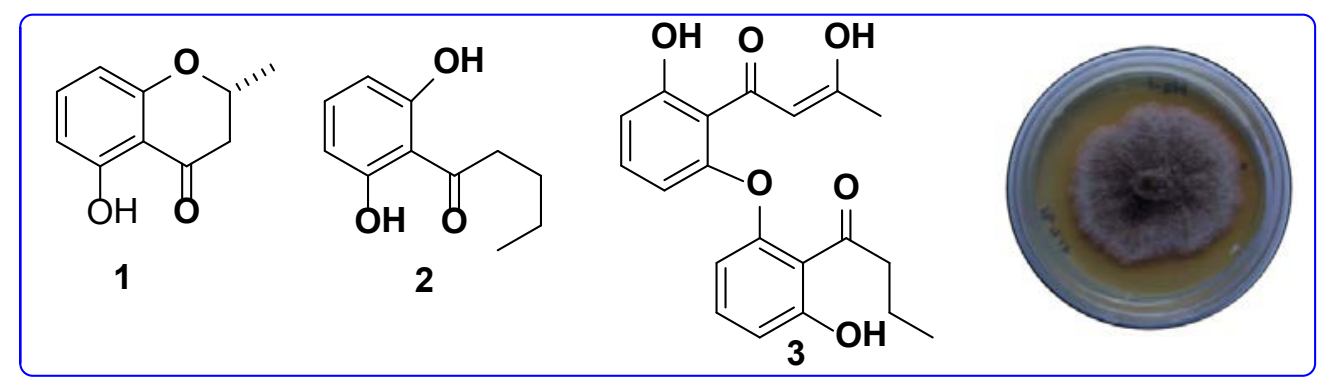

Fig. 1: Structure of compounds (1-3) isolated from H2-1 


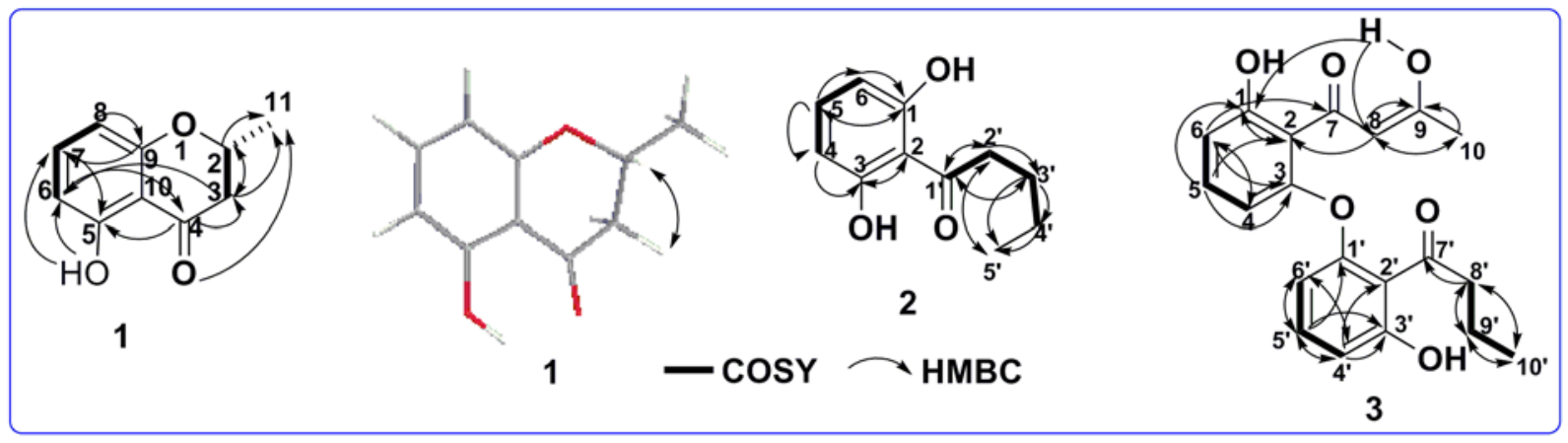

Fig. 2. Selected ${ }^{1} \mathrm{H}-{ }^{1} \mathrm{H}$ COSY $(-), \operatorname{HMBC}(\searrow)$ correlation of $\mathbf{1 , 2}, \mathbf{3}$ and NOESY correlation of 1 


\begin{tabular}{|c|c|c|c|}
\hline \multirow{2}{*}{ A $\begin{array}{c}\text { Sample } \\
\text { Code }\end{array}$} & \multicolumn{3}{|c|}{$\mathrm{IC}_{50}, \mu \mathrm{g} / \mathrm{ml}$ of compounds } \\
\cline { 2 - 5 } & $\begin{array}{c}\text { HL-60 } \\
\text { Leukemia }\end{array}$ & $\begin{array}{c}\text { MiaPaca-2 } \\
\text { Pancreatic }\end{array}$ & $\begin{array}{c}\text { PC-3 } \\
\text { Prostate }\end{array}$ \\
\cline { 2 - 5 } & $\mathbf{1}$ & $\mathbf{1 6}$ & $\mathbf{8 6}$ \\
\hline $\mathbf{2}$ & $\mathbf{1 6}$ & $\mathbf{3 6}$ & 98 \\
\hline 3 & $>100$ & $>100$ & $>100$ \\
\hline
\end{tabular}

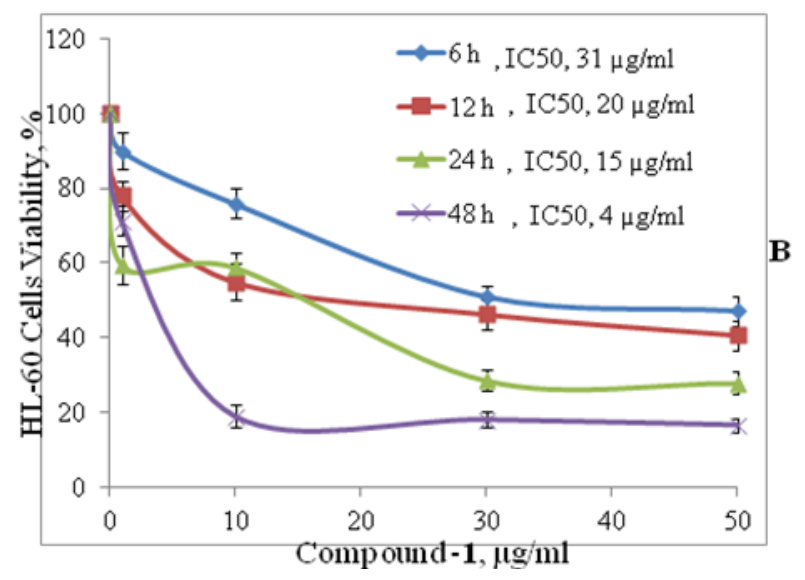

Fig. 3. Cytotoxic profile of isolated compounds (1-3), in different panel of cancer cell lines. A) Human leukemia HL-60 human pancreatic MiaPaca-2 and human prostate PC-3 cells were grown in 96-well culture plate were treated with $1,10,30$ and $50 \mu \mathrm{g} / \mathrm{ml}$ concentration of Compounds (1-3) for $48 \mathrm{~h}$. Cells were incubated with MTT and OD measured at $570 \mathrm{~nm}$ and IC50 was calculated from the graph of OD and cell viability \%. B) Time dependant cytotoxic profile of 1 in human leukemia HL-60 cells. HL-60 cells were treated with indicated time intervals and all the remaining methods and condition were same as described above. Data are Mean $\pm \operatorname{SD}(n=8$ wells), and representative of three similar experiments. 

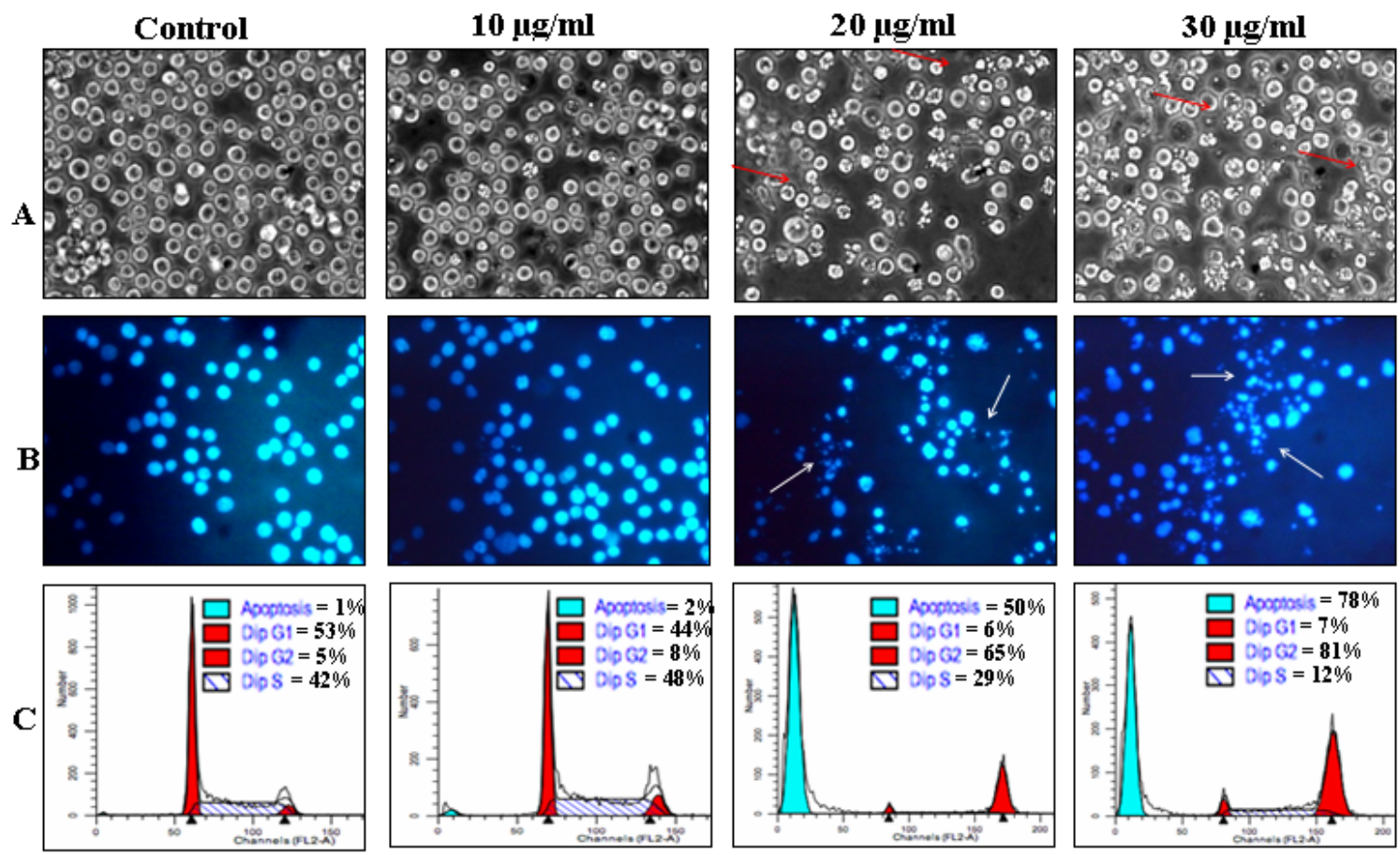

Fig. 4. A-B) Effect of compound 1 on the cell wall and nuclear morphology of HL-60 cells. HL-60 cells were treated with 10,20 and $30 \mu \mathrm{g} / \mathrm{ml}$ concentrations of $\mathbf{1}$ for $24 \mathrm{~h}$ and visualized under phase contrast inverted microscope (Olympus 1X 70). Subsequently cells were stained with Hoechst 33258 as described in Materials \& Methods and visualized for nuclear morphology and apoptotic bodies' formation. Condensed nuclei and the apoptotic bodies are indicated by arrows. Data are representative of one of three similar experiments. C) DNA cell cycle analyses in HL-60 cells exposed to compound 1 with indicated concentrations for $24 \mathrm{~h}$ time period. After treatment cells were stained with Propidium iodide, PI $(10 \mu \mathrm{g} / \mathrm{ml})$ to determine DNA fluorescence and cell cycle phase distribution as described in Materials and methods. Fraction of cells from apoptotic, G1, S and G2 phases analyzed through Modfit software are shown in \%. Data are representative of one of three similar experiments. 
Table 1. NMR data of compound (1) ${ }^{\text {a }}$ Position

\begin{tabular}{|c|c|c|c|c|}
\hline No. & $\begin{array}{l}\delta_{\mathrm{H}} \\
\text { (mult. } J \text { in }[\mathrm{Hz}] \text { ) }\end{array}$ & $\delta_{\mathrm{C}}$ & ${ }^{1} \mathrm{H}-{ }^{1} \mathrm{H}-\mathrm{COSY}$ & HMBC \\
\hline 1 & --- & --- & & \\
\hline 2 & $4.59(1 \mathrm{H}, \mathrm{m})$ & 73.8 & H-3, H-11 & 3,11 \\
\hline 2-Me & $1.51(3 \mathrm{H}, \mathrm{d}, 6)$ & 20.8 & $\mathrm{H}-2, \mathrm{H}-3$ & 3 \\
\hline $3 a$ & $2.78(1 \mathrm{H}, \mathrm{dd}, 17.2,11.6)$ & 43.8 & H-2, H-11 & $11,4,6$ \\
\hline $3 b$ & $2.68(1 \mathrm{H}, \mathrm{dd}, 17.2,11.6)$ & --- & $\mathrm{H}-2, \mathrm{H}-11$ & $11,4,6$ \\
\hline 4 & --- & 198.5 & & 3,11 \\
\hline 5 & --- & 162.1 & & 6,7 \\
\hline $5-\mathrm{OH}$ & $11.70(1 \mathrm{H}, \mathrm{s})$ & --- & & 6,7 \\
\hline 6 & $6.50(1 \mathrm{H}, \mathrm{d}, 8.4)$ & 109.1 & $\mathrm{H}-7$ & 4 \\
\hline 7 & $7.34(1 \mathrm{H}, \mathrm{t}, 8.4)$ & 138.1 & H-6 & 5,6 \\
\hline 8 & $6.43(1 \mathrm{H}, \mathrm{d}, 8.0)$ & 107.3 & $\mathrm{H}-8$ & 9 \\
\hline 9 & -- & 161.7 & --- & 7 \\
\hline 10 & -- & 108.0 & --- & 3,9 \\
\hline
\end{tabular}

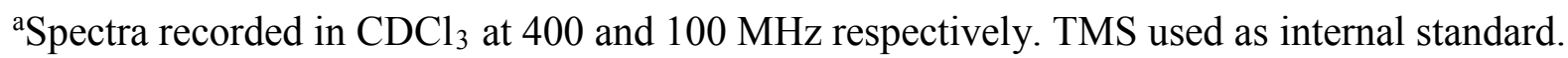


Table 2. NMR data of compound (2) ${ }^{\text {a }}$ Position

\begin{tabular}{|c|c|c|c|c|}
\hline No. & $\begin{array}{l}\delta_{\mathrm{H}} \\
\text { (mult. } J \text { in }[\mathrm{Hz}])\end{array}$ & $\delta_{\mathrm{C}}$ & ${ }^{1} \mathrm{H}-{ }^{1} \mathrm{H}-\mathrm{COSY}$ & HMBC \\
\hline 1 & --- & 161.1 & & 5 \\
\hline $1-\mathrm{OH}$ & $9.51(1 \mathrm{H}, \mathrm{s})$ & --- & & \\
\hline 2 & --- & 110.1 & & 3 \\
\hline 3 & --- & 160.8 & & 2 \\
\hline $3-\mathrm{OH}$ & $9.51(1 \mathrm{H}, \mathrm{s})$ & --- & & \\
\hline 4 & $6.39(1 \mathrm{H}, \mathrm{d}, 8.4)$ & 108.4 & $\mathrm{H}-5$ & 3 \\
\hline 5 & $7.23(1 \mathrm{H}, \mathrm{t}, 8.0)$ & 110.1 & H-6 & $1,4,6$ \\
\hline 6 & $6.39(1 \mathrm{H}, \mathrm{d}, 8.4)$ & 108.4 & $\mathrm{H}-5$ & 1 \\
\hline $1^{\prime}$ & --- & 207.6 & & $2^{\prime}, 3^{\prime}$ \\
\hline $2^{\prime}$ & $3.12(2 \mathrm{H}, \mathrm{t}, 8.0)$ & 46.6 & H-3' & $1^{\prime}, 3^{\prime}, 5^{\prime}$ \\
\hline $3^{\prime}$ & $1.77(2 \mathrm{H}, \mathrm{dd}, 7.4,7.4)$ & 29.7 & $\mathrm{H}-2^{\prime}$ & $1^{\prime}, 2^{\prime}, 4^{\prime}, 5^{\prime}$ \\
\hline $4^{\prime}$ & $1.25(2 \mathrm{H}, \mathrm{s})$ & 17.7 & H-3' & $5^{\prime}$ \\
\hline $5^{\prime}$ & $1.01(3 \mathrm{H}, \mathrm{t}, 7.2)$ & 13.8 & & $2^{\prime}$ \\
\hline
\end{tabular}

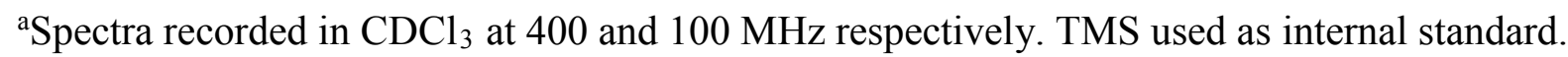


Table 3. NMR data of compound (3) ${ }^{\text {a }}$ Position

\begin{tabular}{|c|c|c|c|c|}
\hline No. & $\begin{array}{l}\delta_{\mathrm{H}} \\
\text { (mult. } J \text { in }[\mathrm{Hz}])\end{array}$ & $\delta_{\mathrm{C}}$ & ${ }^{1} \mathrm{H}-{ }^{1} \mathrm{H}-\mathrm{COSY}$ & HMBC \\
\hline 1 & --- & 160.6 & & 5 \\
\hline $1-\mathrm{OH}$ & $9.92(1 \mathrm{H}, \mathrm{s})$ & & & \\
\hline 2 & --- & 110.3 & & 3 \\
\hline 3 & --- & 156.8 & & 2 \\
\hline 4 & $6.80,(1 \mathrm{H}, \mathrm{d}, 9.2)$ & 111.3 & H-5, H-6 & $1,2,6$ \\
\hline 5 & $7.53(1 \mathrm{H}, \mathrm{t}, 8.3)$ & 135.6 & H-4, H-6 & $1,2,3$ \\
\hline 6 & $6.89(1 \mathrm{H}, \mathrm{d}, 9.2)$ & 107.1 & $\mathrm{H}-4, \mathrm{H}-5$ & $4,7,3$ \\
\hline 7 & --- & 183.7 & & \\
\hline 8 & $6.13(1 \mathrm{H}, \mathrm{s})$ & 109.5 & & $10,2,7,9$ \\
\hline 9 & & 168.0 & & \\
\hline $9-\mathrm{OH}$ & $12.47(1 \mathrm{H}, \mathrm{s})$ & & & 8,5 \\
\hline 10 & $2.40(3 \mathrm{H}, \mathrm{s})$ & 20.6 & & 8,9 \\
\hline $1^{\prime}$ & & 161.3 & & \\
\hline $2^{\prime}$ & & 110.1 & & \\
\hline $3^{\prime}$ & & 161.3 & & \\
\hline 3'-OH & $9.92(\mathrm{~s}, 1 \mathrm{H})$ & & & \\
\hline $4^{\prime}$ & $6.41(1 \mathrm{H}, \mathrm{d}, 8.4)$ & 108.5 & H-5', H-6' & $6^{\prime}, 3^{\prime}, 7^{\prime}, 2^{\prime}, 4^{\prime}, 1^{\prime}$ \\
\hline $5^{\prime}$ & $7.21(1 \mathrm{H}, \mathrm{t}, 8.13)$ & 136.0 & H-4', H-6' & $4^{\prime}, 6^{\prime}, 3^{\prime}, 1^{\prime}$ \\
\hline $6^{\prime}$ & $6.41(1 \mathrm{H}, \mathrm{d}, 8.4)$ & 108.5 & H-4', H-5' & \\
\hline $7^{\prime}$ & & 207.8 & & \\
\hline $8^{\prime}$ & $3.13(2 \mathrm{H}, \mathrm{t}, 7.3)$ & 46.7 & H- 9', H-10' & $10^{\prime}, 9^{\prime}, 7^{\prime}$ \\
\hline $9^{\prime}$ & $1.77(2 \mathrm{H}, \mathrm{dd}, 7.6,7.2)$ & 17.7 & H-8', H-10' & $7^{\prime}, 8^{\prime}, 10^{\prime}$ \\
\hline $10^{\prime}$ & $1.00(3 \mathrm{H}, \mathrm{t}, 7.4)$ & 13.9 & H-8', H-9' & $9^{\prime}, 8^{\prime}$ \\
\hline
\end{tabular}

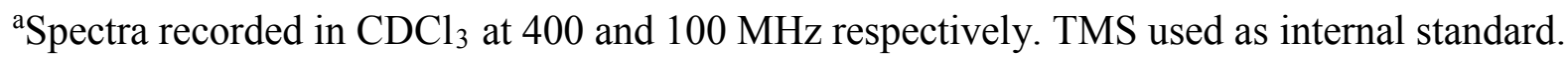


Table 4. A Summary of antimicrobial activities of the compounds (1-3). Compound 1 as not active against any of the strains up to a concentration of $100 \mu \mathrm{g} / \mathrm{ml}$. Pathogens were growth in the medium containing different concentrations of each compound and absorbance was measured spectrophotometrically at $620 \mathrm{~nm}$. $\mathrm{IC}_{50}$ of the extracts was calculated from the average percent inhibition (in comparison with the relevant controls) of three replicates of each concentration

\begin{tabular}{|c|c|c|c|c|}
\hline \multirow[t]{2}{*}{ S. No. } & \multirow[t]{2}{*}{ Pathogens } & \multicolumn{3}{|c|}{ IC $_{50}(\mu \mathrm{g} / \mathrm{ml})$ of Compounds } \\
\hline & & 1 & 2 & 3 \\
\hline 1 & Alcaligenes faecalis MTCC 126 & - & - & - \\
\hline 2 & Bacillus cereus & - & 20 & 20 \\
\hline 3 & Clostridium pasteurianum MTCC 116 & - & - & - \\
\hline 4 & Escherichia coli ATCC 25922 & - & 30 & 50 \\
\hline 5 & Escherichia coli $\mathrm{O} 157: \mathrm{H} 7$ ATCC 35150 & - & - & - \\
\hline 6 & Klebsiella pneumoniae & - & - & - \\
\hline 7 & Listeria monocytogenes ATCC 15313 & - & 60 & 75 \\
\hline 8 & Pseudomonas fluorescens MTCC 103 & - & 47 & 6 \\
\hline 9 & Salmonella typhimurium MTCC 98 & - & - & - \\
\hline 10 & Shigella flexneri ATCC 12022 & - & 92 & - \\
\hline 11 & Staphylococcus aureus ATCC 29978 & - & 18 & 51 \\
\hline 12 & Staphylococcus aureus P1571 & - & 15 & 24 \\
\hline 13 & Staphylococcus epidermidis MTCC 435 & - & - & - \\
\hline 14 & Streptococcus pyogenes MTCC 442 & - & - & 62 \\
\hline 15 & Yersinia enterocolitica MTCC 840 & - & - & - \\
\hline 16 & Candida albicans MTCC 4748 & - & - & - \\
\hline
\end{tabular}


